\title{
Edukasi Kesehatan dalam Upaya Pencegahan Penyakit Skabies di Pondok Pasantren Madrasah Tsanawiyah Harsallakum Kota Bengkulu
}

\section{Health Education in Efforts to Prevent Scabies at Islamic Boarding School of Harsallakum Madrasah Tsanawiyah Bengkulu}

\author{
Inayah Hayati*1, Eka Nurdianty Anwar ${ }^{1}$, Muhammad Yandi Syukri ${ }^{2}$ \\ ${ }^{1}$ Akademi Analis Kesehatan Harapan Bangsa Bengkulu, Jl. Depati Payung Negara, Padang Kemiling, Kota \\ Bengkulu, Indonesia \\ ${ }^{2}$ Madrasah Aliyah Negeri 2 Kota Bengkulu, Jl. Bandara Fatmawati, Bengkulu, Indonesia
}

\begin{tabular}{|c|c|}
\hline Info Artikel & ABSTRAK \\
\hline $\begin{array}{l}\text { Diterima 16 Maret } 2021 \\
\text { Ditelaah 08 Juni } 2021 \\
\text { Disetujui 25 Juni } 2021 \\
\text { Tersedia daring 30 Juni } 2021 \\
\text { *Penulis untuk korespondensi } \\
\text { inayah1807@gmail.com }\end{array}$ & $\begin{array}{l}\text { Penyakit skabies merupakan penyakit kulit yang disebabkan oleh parasit Sarcoptes } \\
\text { scabiei yang menginvasi kulit manusia atau hewan. Prevalensi skabies yang tinggi } \\
\text { umumnya ditemukan di lingkungan dengan kepadatan penghuni dan kontak } \\
\text { interpersonal tinggi seperti penjara, pondok pasantren, dan panti asuhan. Belum ada } \\
\text { penelitian mengenai prevalensi penyakit skabies di Pondok Pesantren Harsallakum kota } \\
\text { Bengkulu. Namun, berdasarkan informasi dari pihak sekolah terdapat beberapa anak } \\
\text { yang pernah terinfeksi penyakit kulit dengan gejala klinis infeksi skabies. Program } \\
\text { pengabdian masyarakat bertujuan untuk memberikan edukasi kepada santri tentang }\end{array}$ \\
\hline $\begin{array}{l}\text { Kata Kunci: } \\
\text { Skabies, } \\
\text { Edukasi Kesehatan, } \\
\text { Pondok Pasantren }\end{array}$ & $\begin{array}{l}\text { penyampaian materi tentang skabies, pembagian leaflet, post-test dan pre-test. Kegiatan } \\
\text { ini diikuti oleh } 65 \text { peserta. Evaluasi meliputi pre-test dan post-test tentang edukasi yang } \\
\text { dilakukan. Instrumen untuk mengukur tingkat pemahaman siswa berupa kuisioner. Nilai } \\
\text { rata-rata pre-test adalah } 55,18 \text { sedangkan nilai rata-rata postes adalah } 80,26 \text {. } \\
\text { Disimpulkan bahwa kegiatan edukasi ini dapat meningkatkan pengetahuan santri } \\
\text { Pondok Pasantren Harsallakum Kota Bengkulu mengenai penyakit skabies. Untuk } \\
\text { mengoptimalkan pencegahan penularan penyakit skabies, disarankan untuk } \\
\text { memperbanyak kegiatan edukasi kesehatan dengan melibatkan tenaga kesehatan. }\end{array}$ \\
\hline
\end{tabular}

Keywords:

Scabies,

Health Education,

Boarding School

\begin{abstract}
Scabies is a skin disease caused by the Sarcoptes scabiei parasite that invades the skin of humans or animals. The high prevalence of scabies is generally found in environments with high population density and high interpersonal contacts such as prisons, Islamic boarding schools, and orphanages. There has been no research on the prevalence of scabies in the Harsallakum Islamic Boarding School, Bengkulu city. However, based on information from the school, there were several students who have been infected by skin disease with clinical symptoms of scabies. This community service program was aimed to provide education to students about preventing scabies infection. The service activities included delivering material about scabies, distributing leaflets, post-test and pre-test. This activity was attended by 65 participants. Evaluation included pre-test and post-test about the education carried out. The instrument to measure the level of students' understanding was the form of a questionnaire. The average value of the pre-test was 55.18 while the average value of the post-test was 80.26 . It was concluded that this educational activity could increase the knowledge of the students of the Harsallakum Islamic Boarding School in Bengkulu about scabies disease. To optimize the prevention of scabies transmission, it is recommended to increase health education activities by involving health workers.
\end{abstract}

ISSN 2685-0354 (Media Online). Diterbitkan oleh Universitas Prof. Dr. Hazairin, SH. Ini merupakan jurnal bebas akses di bawah lisensi Creative Commons Atribution 4.0 International (https://creativecommons.org/licenses/by/4.0 


\section{PENDAHULUAN}

Penyakit skabies merupakan penyakit kulit dengan insidensi dan prevalensi yang tinggi di seluruh dunia, terutama di daerah beriklim tropis dan subtropis (Hilma \& Ghazali, 2014). Diagnosis skabies dapat ditegakkan melalui keberadaan tungau, larva, telur atau kotoran melalui pemeriksaan mikroskopis (Perhimpunan Dokter Spesialis Kulit dan Kelamin Indonesia, 2017). Kelainan klinis pada kulit yang ditimbulkan oleh infestasi Sarcoptes scabiei sangat bervariasi. Tanda utama atau tanda kardinal pada infestasi skabies yaitu pruritus nokturna, ditemukannya terowongan (kunikulus) dan ditemukan parasit Sarcoptes scabiei. Gatal yang terjadi disebabkan oleh sensitisasi terhadap sekret dan ekskret tungau yang memerlukan waktu kurang lebih satu bulan setelah infestasi. Pada saat itu, kelainan kulit menyerupai dermatitis dengan ditemukannya papul, vesikel, urtikaria dan lain-lain. Garukan dapat menimbulkan erosi, ekskoriasi, krusta dan infeksi sekunder (Djuanda, 2010).

Pada umumnya lingkungan yang padat seperti pondok pasantren, asrama, dan panti asuhan merupakan lingkungan beresiko tertular penyakit menular seperti penyakit skabies. Menurut penelitian Al Audhah et al. (2012) di Pondok Pesantren Darul Hijah terdapat hubungan yang bermakna antara kepadatan hunian dengan kejadian skabies dengan $\mathrm{OR}=3,6$. Kepadatan hunian yang tinggi akan meningkatkan risiko kejadian skabies 3,6 kali dibandingkan dengan kepadatan hunian yang rendah. Hal ini dikarenakan kepadatan hunian yang tinggi, terutama pada kamar tidur, menyebabkan kontak langsung antar santri menjadi tinggi sehingga memudahkan terjadinya penularan skabies dari satu santri ke santri lainnya.

Faktor yang paling berpengaruh terhadap prevalensi skabies adalah perilaku. Hasil penelitian Setyaningrum (2016) menunjukkan adanya hubungan secara langsung antara jenis kelamin, lingkungan fisik dan perilaku hidup bersih dan sehat (PHBS) terhadap prevalensi skabies. Hal ini didukung juga oleh penelitian Akmal et al., (2013) bahwa kejadian penyakit skabies ada hubungannya dengan personal hygiene di pondok pasantren Islam Darul Ulum Padang. Personal hygiene yang tidak baik merupakan salah satu faktor yang bisa meningkatkan kejadian skabies (Yunita M et al., 2018).

Berdasarkan hasil penelitian Sukiman (2017), disimpulkan adanya hubungan antara personal hygiene dan kepadatan hunian dengan kejadian skabies pada santri di pondok pesantren Al Mubaarak Kota Bengkulu. Terdapat beberapa Pondok Pasanteren di kota Bengkulu, dan salah satunya adalah Pondok pesantren Al Qur'an Harsallakum. Pondok Pasanteren ini terletak di Jalan Hibrida Ujung RT. 9 Kelurahan Pagar Dewa Kecamatan Selebar Kota Bengkulu dengan tujuan membentuk santri yang beriman, bertaqwa dan berakhlak mulia dan berprestasi dalam bidang pendidikan, dakwah, seni, olahraga dan keterampilan praktis (Pondok Pasantren Harsallakum, 2018).

Berdasarkan informasi wawancara yang diperoleh dari bagian Unit Kesehatan Sekolah, pernah ada kasus atau terjangkitnya penyakit gatal-gatal pada kulit dengan keluhan rasa gatal-gatal pada malam hari. Pada umumnya, santri tidak tahu penyebab penyakit kulit yang mereka rasakan. Belum diketahui prevalensi angka infeksi skabies di pondok pasantren dan belum pernah dilakukan penyuluhan kesehatan yang berkaitan dengan upaya pencegahan penyakit skabies. Oleh karena itu, perlu dilakukan upaya dari tim pengabdian untuk memberikan pengetahuan kepada santri dengan edukasi kesehatan. Menurut Notoatmodjo (2012), edukasi kesehatan adalah aplikasi atau penerapan pendidikan di dalam bidang kesehatan. Secara operasional, edukasi kesehatan adalah semua kegiatan untuk memberikan dan meningkatkan pengetahuan, sikap, dan praktik baik individu, kelompok atau masyarakat dalam memelihara dan meningkatkan kesehatan masyarakat. Berdasarkan hasil penelitian Sidiq (2018), pemberian edukasi dengan metode ceramah efektif terhadap peningkatan pengetahuan personal hygiene pada tahanan di rumah tahanan negara klas IIB Wates Kulon Progo. Oleh karena, pengabdian masyarakat ini bertujuan mengetahui peningkatan pengetahuan melalui edukasi kesehatan terkait penyakit skabies pada santri Pondok Pasantren Harsallakum Kota Bengkulu.

\section{METODE}

Kegiatan pengabdian pada masyarakat telah dilaksanakan pada bulan November 2019 di Aula Pondok Pesantren Harsallakum Kota Bengkulu yang terletak di Jl. Hibrida Kecamatan Selebar Kota Bengkulu. Tahap awal yang dilakukan adalah sosialisasi dan perijinan kepada pihak sekolah MTs. Alquran Harsallakum Kota Bengkulu sebelum pelaksanaan kegiatan. Peserta yang hadir dalam kegiatan ini berjumlah 65 santri. Edukasi kesehatan dilakukan dengan cara penyampaian materi skabies dengan metode ceramah menggunakan alat pendukung berupa media laptop, LCD Proyektor (infocus), dan leaflet. Instrumen yang digunakan dalam kegiatan ini adalah kuisioner meliputi pre-test dan post-test. Kuisioner ini dibagikan untuk melihat peningkatan pengetahuan santri tentang penyakit 
skabies setelah edukasi kesehatan dan media yang dibagikan oleh narasumber. Butir soal mencakup tentang penyebab, cara penularan, resiko terkena, gejala klinis, pengobatan dan pencegahan penyakit skabies.

Langkah awal dari kegiatan pengabdian ini berupa kegiatan pre-test. Pengerjaan soal pre-test dalam waktu 15 menit untuk setiap peserta kegiatan. Jawaban pre-test kemudian dikumpulkan. Setelah itu dilanjutkan dengan penyampaian materi dan media leaflet tentang skabies kepada santri pondok pesantren Harsallakum yang mengikuti kegiatan. sesi diskusi berupa tanya jawab antara peserta dengan narasumber dilakukan setelah penyampaian materi. Proses diskusi selain memberikan kesempatan bagi peserta untuk memperluas wawasan juga merupakan bagian konfirmasi terhadap penyuluhan yang diberikan. Pada kegiatan pos-test, dilakukan hal yang sama dengan kegiatan pre-test yang berkaitan dengan materi yang telah disampaikan tentang penyakit kulit skabies. Data dianalisis dengan uji T-test untuk melihat peningkatan pengetahuan sebelum dan sesudah penyampaian edukasi.

\section{HASIL DAN PEMBAHASAN}

Kegiatan pengabdian kepada masyarakat yang telah dilaksanakan oleh Tim Pengabdian telah diikuti oleh 65 santriwati kelas VIII MTs. Pondok Pasantren Harsallakum Kota Bengkulu. Berdasarkan informasi dari pihak sekolah, pernah ada siswa yang terinfeksi penyakit skabies dan belum pernah dilakukannya pemberian edukasi kesehatan tentang penyakit ini. Kegiatan diawali dengan memberikan kuisioner untuk menggali informasi apakah santri pernah mendapatkan informasi dari berbagai sumber misal petugas kesehatan/internet/ustad/ustadzah tentang penyakit skabies. Informasi yang terkumpul menunjukkan bahwa 58 orang santri belum pernah mendapatkan pengetahuan tentang penyakit skabies dari petugas kesehatan atau dari sumber yang lain, 7 orang santri mengetahui sedikit informasi penyakit skabies dari internet. Dari pertanyaan tentang informasi penyakit skabies hampir $85 \%$ santri belum pernah mendapatkan informasi mengenai penyakit skabies.

Pre-test dilakukan dengan soal sebanyak 20 butir yang berkaitan dengan pengetahuan tentang penyakit skabies meliputi: penyebab, cara penularan, gejala yang ditimbulkan, pencegahan dan pengobatan. Kegiatan ini dibatasi waktu selama 15 menit yang bertujuan untuk menentukan pengetahuan santri sebelum penyampaian materi edukasi kesehatan dalam upaya pencegahan penyakit skabies. Materi disampaikan tim pengabdi yang yang memiliki kompetensi bidang parasitologi (Gambar 1).

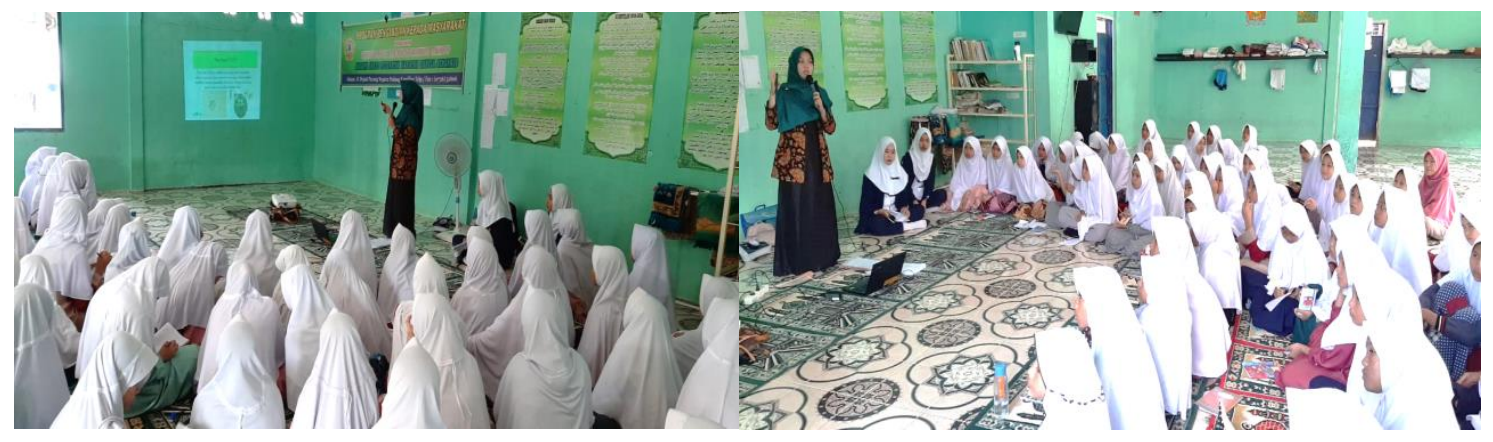

Gambar 1 Penyampaian materi dan diskusi dengan santri

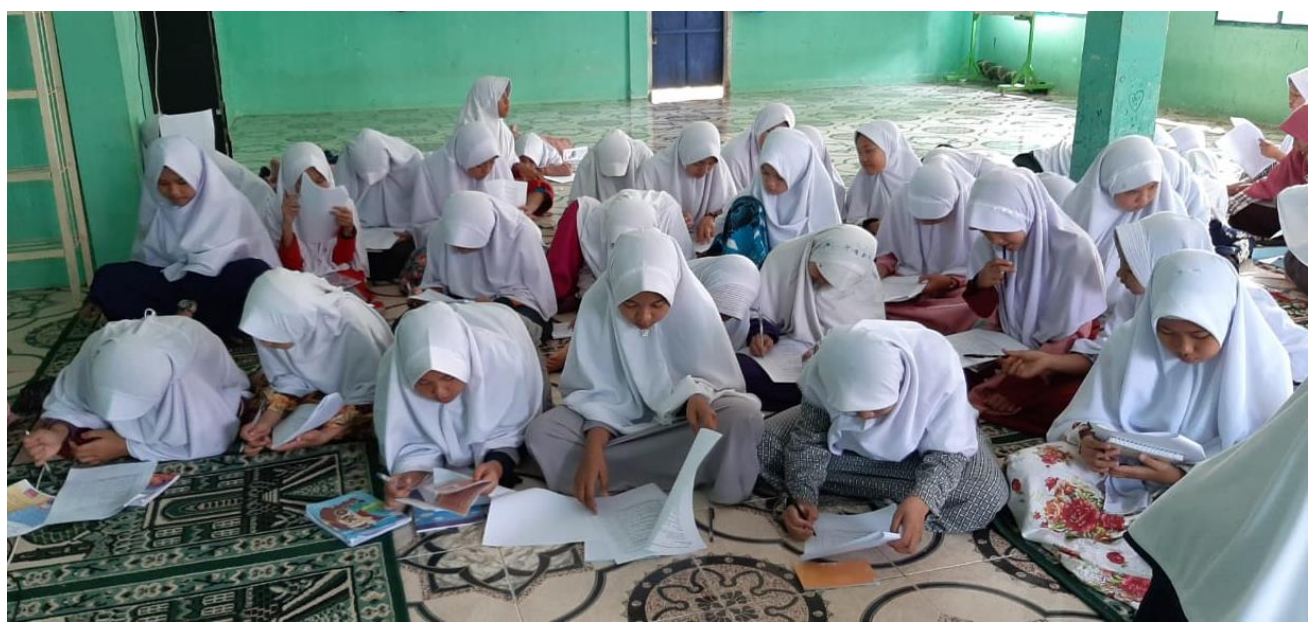

Gambar 2 Santri menjawab pertanyaan post-test setelah penyampaian materi 
Diskusi yang terjadi menunjukkan antusiasme peserta. Para santriwati mengajukan pertanyaan seputar materi yang berkaitan dengan penyakit kulit skabies. Setelah penyampaian materi dan diskusi, kegiatan dilanjutkan dengan pembagian kuisoner yang berisi pertanyaan yang berkaitan materi yang telah disampaikan dalam bentuk post-test (Gambar 2).

Pengetahuan peserta penyuluhan diketahui melalui kuesioner yang disebarkan sebelum dan sesudah kegiatan edukasi. Aspek yang dinilai mencakup tentang penyebabnya, cara penularan, gejala klinis, obat-obat yang digunakan untuk skabies dan upaya pecegahan agar tidak terinfeksi skabies. Berdasarkan analisa jawaban pada pre-test, tingkat pemahaman santri tentang cara penularan dan penyebab masih rendah. Dari 65 responden yang menjawab benar hanya 10 orang santri. Sedangkan setelah pelaksanaan post-test tingkat pemahaman pada aspek cara penularan, penyebab dan cara pencegahan meningkat. Hasil pre-test-post-test menunjukkan adanya peningkatan pengetahuan santri tentang penyakit skabies yang diperoleh dari hasil rata-rata (Tabel 1).

Tabel 1. Nilai rata -rata Pengetahuan Santri Sebelum dan Sesudah Diberikan Edukasi Kesehatan tentang Penyakit Skabies di Pondok Pasantren Harsallakum Kota Bengkulu

\begin{tabular}{llll}
\hline & Nilai rata-rata hasil tes & Standar deviasi & Probabiliti (sig.) uji T \\
\hline Pre-test & 55,1846 & 10,79770 & $0.000(<0.05)$ \\
Post-test & 80,2615 & 6,59374 & \\
\hline
\end{tabular}

Distribusi nilai rata-rata pengetahuan pada santri Pondok Pasantren Harsallakum Kota Bengkulu Tahun 2019 menunjukkan rata-rata nilai pre-test adalah 55,1846 dan rata-rata nilai post-test adalah 80,2615 . Nilai sig $=0,000$ $(<0,05)$ dari uji $\mathrm{T}$ dengan menggunakan rerata pre-test dan post-test menunjukkan adanya peningkatan tingkat pengetahuan santri yang signifikan tentang penyakit skabies setelah diberikannya edukasi kesehatan.

Edukasi kesehatan dilakukan dengan metode ceramah dan media berupa leaflet berwarna. Menurut penelitian Haryani (2015) menyimpulkan bahwa media dalam promosi kesehatan merupakan salah satu upaya untuk mendukung keberhasilan proses pembelajaran sehingga lebih menarik perhatian dan materi yang disampaikan akan lebih mudah dipahami oleh peserta. Hal ini juga didukung oleh pernyataan Notoatmodjo (2010), yaitu promosi kesehatan menggunakan metode ceramah dan media membuat situasi pembelajaran lebih menyenangkan, kreatif dan tidak membosankan. Media promosi kesehatan adalah upaya menampilkan pesan atau informasi yang ingin disampaikan oleh komunikator, baik melalui media cetak, elektronika, dan media luar ruang, sehingga pengetahuan pesert dapat meningkat dan akhirnya dapat mengubah perilaku ke arah positif terhadap kesehatan.

Dengan adanya edukasi kesehatan, santri di pondok pasantren diharapkan terhindar dari penularan penyakit skabies. Menurut penelitian Aminah et al. (2015), terdapat hubungan antara tingkat pengetahuan dengan kejadian skabies. Pengetahuan diharapkan dapat membantu terhindari dari resiko penularan penyakit skabies. Tingkat pengetahuan tidak semata-mata dipengaruhi oleh proses pelaksanaan pendidikan. World health organization (WHO) menyatakan faktor lain yang juga mempengaruhi, antara lain motivasi, kebutuhan terhadap informasi, pengalaman. Pengetahuan tentang penyakit skabies dapat mengubah sikap dan perilaku tentang praktik kebersihan diri sehingga dapat menurunkan angka kejadian skabies. Penelitian serupa dilakukan oleh Ummul (2011) yang meneliti tentang faktor-faktor yang berhubungan dengan kejadian skabies di Pondok Pesantren Darul Huffadh di wilayah kerja Puskesmas Kajuara Kabupaten Bone. Hasil penelitian ini menjelaskan bahwa faktor-faktor yang berpengaruh terhadap kejadian skabies di antaranya tingkat pengetahuan ( $\mathrm{p}$-value $=0,000)$, praktik kebersihan diri $(\mathrm{p}$-value $=0,000)$, dan sikap (p-value $=0,000)$. Tingkat pengetahuan seseorang merupakan hal yang sangat penting yang berperan dalam terbentuknya tindakan seseorang mengenai suatu penyakit baik berupa deteksi dini hingga upaya terhadap pencegahan penyakit.

Untuk mengetahui bagaimana cara pencegahan skabies, santri juga harus memahami siklus hidup tungau sebagai pathogen dari penyakit skabies. Siklus hidup Sarcoptes scabiei diawali oleh masuknya tungau dewasa ke dalam kulit manusia dan membuat terowongan di stratum korneum sampai akhirnya tungau betina bertelur. Sarcoptes scabiei tidak dapat menembus lebih dalam dari lapisan stratum korneum (Ronny, 2010). Oleh karena itu, pencegahan skabies pada manusia dapat dilakukan dengan cara menghindari kontak langsung dengan penderita dan mencegah penggunaan barang-barang penderita secara bersama-sama seperti pakaian, handuk, dan lain-lain. Barang-barang yang pernah digunakan oleh penderita harus diisolasi dan dicuci dengan air panas. Pakaian dan barang-barang asal kain dianjurkan untuk disetrika sebelum digunakan. Sprai penderita harus sering diganti dengan yang baru maksimal tiga hari sekali. Benda - benda yang tidak dapat dicuci dengan air (bantal, guling, selimut) disarankan dimasukkan kedalam kantung plastic selama tujuh hari, selanjutnya dicuci kering atau dijemur di bawah sinar matahari. 
Kebersihan tubuh dan lingkungan termasuk sanitasi serta pola hidup yang sehat akan mempercepat kesembuhan dan memutu siklus hidup Sarcoptes scabiei (Arlian \& Morgan, 2017).

Adanya peningkatan pengetahuan santri sesudah diberikan pendidikan kesehatan tentang pencegahan penyakit skabies dipengaruhi oleh cara penyampaian materi, metode dan alat bantu yang digunakan seperti leaflet. Dalam hal ini leaflet dapat membantu dan mempermudah proses pemahaman santri terhadap pencegahan penyakit skabies.

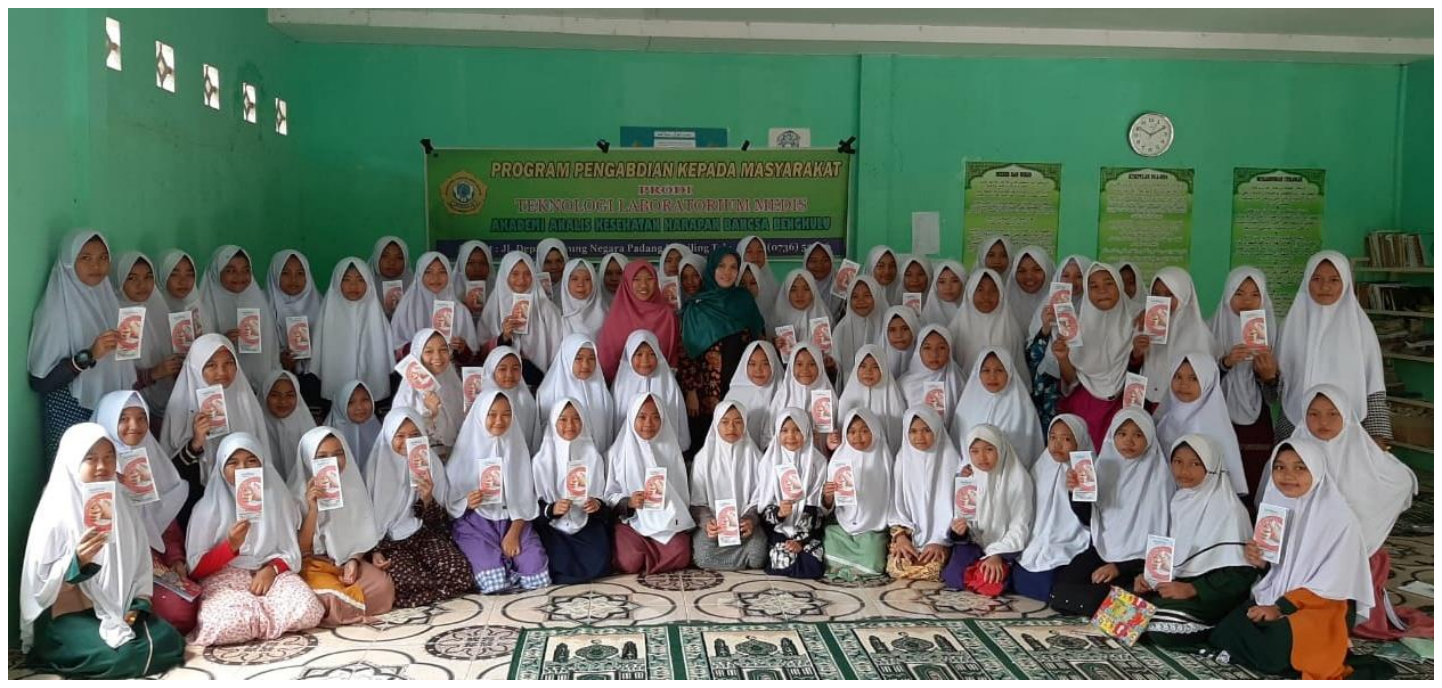

Gambar 3 Peserta dan tim pengabdian setelah kegiatan

\section{KESIMPULAN}

Pemahaman tentang berbagai penyakit potensial di tempat-tempat berkerumun sangat diperlukan oleh masyarakat. Salah satu di antaranya adalah asrama atau pondok pesantre. Edukasi tentang penyakit scabies di Pondok Pesantren yang dilakukan pada kegiatan pengabdian pada masyarakat ini memberi hasil yang baik. Terjadi peningkatan pengetahuan yang signifikan tentang penyakit skabies setelah diberikannya edukasi kesehatan. Oleh karena itu, disarankan lebih mengoptimalkan kegiatan yang bersifat informasi kesehatan dengan melibatkan instansi kesehatan terdekat untuk memfasilitasi berbagai masalah kesehatan di lingkungan pondok pasantren.

\section{DAFTAR PUSTAKA}

Akmal, S. C., Semiarty, R., \& Gayatri, G. (2013). Hubungan personal hygiene dengan kejadian skabies di Pondok Pendidikan Islam Darul Ulum, Palarik Air Pacah, Kecamatan Koto Tangah Padang Tahun 2013. Jurnal Kesehatan Andalas, 2(3), 164-167.

Aminah, P., Sibero, H., \& Ratna, M. (2015). Hubungan tingkat pengetahuan dan perilaku santri dengan kejadian skabies. J Mayority, 4(5), 54-59.

Al Audhah, N., Umniyati, S. R., \& Siswati, A. S. (2012). Faktor resiko skabies pada siswa pondok pesantren (Kajian di Pondok Pesantren Darul Hijrah, Kelurahan Cindai Alus, Kecamatan Martapura, Kabupaten Banjar, Provinsi Kalimantan Selatan). Jurnal Buski, 4(1), 14-22.

Arlian, L. G., \& Morgan, M. S. (2017). A review of Sarcoptes scabiei: Past, present and future. Parasites and Vectors, 10(1), 1-22.

Djuanda, A. (2010). Ilmu penyakit kulit dan kelamin. Fakultas Kedokteran Universitas Indonesia

Haryani, W. (2015). Promosi kesehatan gigi meningkatkan status kebersihan gigi mahasiswa. Jurnal Teknologi Kesehatan, 11(2), 120-122.

Hilma, U. D., \& Ghazali, L. (2014). Faktor-faktor yang mempengaruhi kejadian skabies di Pondok Pesantren Mlangi Nogotirto Gamping Sleman Yogyakarta. Jurnal Kedokteran dan Kesehatan Indonesia, 6(3), 148-157.

Notoatmodjo, S.. (2010). Ilmu perilaku kesehatan. Rineka Cipta

Notoatmodjo, S. (2012). Promosi kesehatan dan prilaku kesehatan. Rineka Cipta.

Perhimpunan Dokter Spesialis Kulit dan Kelamin Indonesia. (2017). Panduan Praktik Klinis Bagi Dokter Spesialis 
Kulit dan Kelamin di Indonesia. Perhimpunan Dokter Spesialis Kulit dan Kelamin Indonesia.

Pondok Pasantren Harsallakum. (2018). Profil Pondok Pasantren Harsallakum. Pondok Pasantren Harsallakum

Ronny, P. H. Skabies. Dalam: Adhi D, Mochtar H, Siti A, Editor. (2010). Ilmu Penyakit Kulit dan Kelamin Edisi Keenam. Balai Penerbit FKUI

Setyaningrum, Y. I. (2016). Prevalensi dan analisis penyebab skabies di pondok pesantren Malang Raya sebagai materi pengembangan buku saku tentang skabies dan upaya pencegahannya [Disertasi]. Universitas Negeri Malang.

Sidiq, P. M. (2018). Efektifitas pemberian edukasi dengan metode ceramah terhadap pengetahuan personal hygiene pada Tahanan di Rutan Klas IIIB Wates Kulon Progo [Skripsi]. Universitas Alma Ata Yogyakarta.

Sukiman, B. B. (2017). Hubungan antara personal hygiene dan kepadatan hunian dengan kejadian skabies pada santri di pondok Pasantren Al-Mubaarak Kota Bengkulu [Skripsi]. Universitas Bengkulu.

Ummul, H. (2011). Faktor-Faktor yang berhubungan dengan kejadian skabies di Pondok Pesantren Darul Huffadh di Wilayah Kerja Puskesmas Kajuara Kabupaten Bone. Jurnal Media Kedokteran, 2(4): 1-6.

Yunita M, S., Gustia, R., \& Anas, E. (2018). Faktor-faktor yang berhubungan dengan kejadian skabies di Wilayah Kerja Puskesmas Lubuk Buaya Kota Padang Tahun 2015. Jurnal Kesehatan Andalas, 7(1), 51-58. 